\title{
TO02 THE INTERACTION OF NITROUS OXIDE WITH COBALAMIN-DEPENDENT METHIONINE SYNTHASE
}

\author{
James T. Drummond and Rowena G. Matthews
}

The Department of Biological Chemistry and the Biophysics Research Division, The University of Michigan, Ann Arbor, MI 48109, U. S. A.

Prolonged treatment of patients with the commonly used anaesthetic, nitrous oxide, results in the development of the symptoms of acute cobalamin deficiency. Inactivation of cobalamin-dependent methionine synthase has been demonstrated under these conditions. We have previously demonstrated that methionine synthase can also be inactivated in vitro during turnover under an atmosphere of nitrous oxide [1].

However, only catalytic amounts of the enzyme could be inactivated, because inactivation is a relatively rare event during turnover. We have now developed a method of redox cycling that permits inactivation of several $\mu$ moles of purified enzyme so that chemical events associated with this inactivation can be elucidated. The enzyme is poised in an electrochemical cell in the presence of methyl viologen and $\mathrm{KCl}$ under an atmosphere of $\mathrm{N}_{2} \mathrm{O}$. Because we have previously measured the standard reduction potential of the enzyme-bound $\operatorname{cob}(\mathrm{II})$ alamin/cob(I)alamin couple [2], we can determine the concentration of cob(I)alamin present at equilibrium at the applied potential. We have been able to show that the enzyme loses activity in a first order fashion during redox cycling under $\mathrm{N}_{2} \mathrm{O}$, and that the rate of inactivation varies linearly with the concentration of $\operatorname{cob}(\mathrm{I})$ alamin present at the applied potential. Our results are simply interpreted as indicating that inactivation is associated with reduction of nitrous oxide by enzyme-bound cob(I)alamin. Further experiments to characterize the oxygen product derived from $\mathrm{N}_{2} \mathrm{O}$ and the inactive protein are currently in progress.

1. V. Frasca, B. S. Riazzi, and R. G. Matthews, J. Biol. Chem., 261, 15823 (1986).

2. R. V. Banerjee, S. R. Harder, S. W. Ragsdale and R. G. Matthews, Biochemistry 29, 1129 (1990). 